dr hab. inz. Jarostaw Korzeb, prof. PW

prof. dr hab. inz. Mirostaw Nader

dr inz. Przemyslaw Ilczuk

dr inż. Jan Różowicz

Politechnika Warszawska

\title{
Selected aspects of vibroacoustic interactions analysis in the vicinity of tram lines
}

\section{Wybrane aspekty analizy oddziaływań wibroakustycznych w otoczeniu linii tramwajowych}

\begin{abstract}
The vibroacoustic impacts in the urban agglomeration constitute an important element worsening the comfort of working and resting conditions for the residents. The industrialized zones can be identified as the main surface sources of these impacts, but outside these areas there is a significant number of linear sources such as communication routes. In described areas the point industrial sources and the point moving sources with random or periodic repeatability, which are single journeys of means of transport, can be identified. Dynamic interactions occurring between the superstructure and the exploited transport infrastructure are an important phenomenon and are subject to continuous analysis, due to the multitude of applied solutions of vibroisolation systems. Statistics show that the exposure of urban residents accounts for about $60 \%$ of the total population exposed to vibroacoustic impacts. In the paper the attention was paid to the impacts emitted to the environment for selected types of vibroisolation solutions for a selected tramway track and with the same enforcement. A detailed analysis of the impact occurring in the area of the tram line was made. The research used software prepared by the authors in the Matlab environment.
\end{abstract}

Oddziatywania wibroakustyczne $w$ aglomeracji miejskiej stanowiq ważny element pogarszajacy komfort warunków pracy i odpoczynku dla mieszkańców. Jako główne powierzchniowe źródła tych oddziaływań wskazać można strefy uprzemystowione, ale poza tymi obszarami występuje znaczqca liczba źródel liniowych w postaci szlaków komunikacyjnych. We wskazanych miejscach zidentyfikować można punktowe źródła przemysłowe oraz punktowe źródła ruchome o losowej lub okresowej powtarzalności, które stanowia pojedyncze przejazdy środków transportu. Interakcje dynamiczne zachodzace pomiędzy suprastruktura oraz eksploatowanq infrastruktura transportowa sq zjawiskiem ważnym i podlegaja ciagtym analizom, ze względu na mnogość stosowanych rozwiazań systemów wibroizolacji. Statystyki wykazuja, iż narażenie mieszkańców miast stanowi około $60 \%$ całkowitej populacji społeczeństwa łacznego narażenia na oddziaływania wibroakustyczne. W pracy poddano uwadze oddziatywania emitowane do środowiska dla wybranych typów rozwiazań wibroizolacji wybranego torowiska tramwajowego z zachowaniem tego samego wymuszenia. Poddano szczegółowej analizie oddziatywania występujace $w$ otoczeniu torowiska. W badaniach wykorzystano autorskie oprogramowanie w środowisku Matlab.

\section{INTRODUCTION}

Tram lines are among the main sources of vibroacoustic effects in urban agglomerations $[5,10]$. In the identification process of vibroacoustic interactions sources, one should indicate the rolling noise of steel wheels on the rail heads, impact phenomena related to wheels striking against the rail at crossings and tramway intersections, squealing noise on turns, noise of the drive units, aerodynamic noise or effects of mutual interactions of means of transport and infrastructure originating from forces of inertia [3,11]. In the range of $0-100 \mathrm{~Hz}$, vibrations and noise are transmitted directly by the tram and track structure, with the highest

\section{WSTĘP}

Linie tramwajowe należą do głównych źródeł oddziaływań wibroakustycznych w aglomeracjach miejskich $[5,10]$. W procesie identyfikacji źródeł oddziaływań wibroakustycznych wskazać należy hałas toczenia kół stalowych po główkach szyn, zjawiska typu „impact” związane z uderzeniami kół na rozjazdach i skrzyżowaniach linii tramwajowych, pisk kół na łukach (ang. squealing noise), hałas jednostek napędowych, hałas aerodynamiczny lub efekty oddziaływań wzajemnych środka transportu i infrastruktury pochodzące od sił bezwładności $[3,11]$. W zakresie $0-100$ $\mathrm{Hz}$ drgania i hałas przenoszone są bezpośrednio przez 
values in the frequency ranges of less than $50 \mathrm{~Hz}$, and disappearing faster as their frequencies increase. In the ranges of $30-2000 \mathrm{~Hz}$, the noise directly associated with the tram traffic prevails, with the energy of the vibroacoustic process being propagated to the environment mainly by the wheels and rails for higher frequencies [14].

Noise and vibrations generated by tram traffic can be classified as short-term or temporary [8]. Considering the inconvenience of these vibroacoustic noises, it should also be noted that the network of tram lines is significantly smaller than the road network, therefore the population of people exposed to vibroacoustic noise caused by tram traffic is smaller than the total number of people in the urban area exposed to transport noise [2, 12]. The noise level generated by the passage of a tram depends on the track construction and is a result of: the type of foundations used, rail fastening method, the type of track and ground [13]. The location of the track has a large impact on the amplitude of the generated interactions, as there are large differences between trams driving on bridges, through tunnels and on an even ground level, but the level of maintenance of the ground, rails and sleepers is undeniably also significant [9]. In the case of the tested group of railway vehicles, the vehicle propulsion units and the aerodynamic properties had little influence on the noise these vehicles generated. Due to the short tram noise exposure duration of residents, the noise effects described in the article are relatively short, hence they cannot be considered harmful, but rather as onerous.

\section{EXPERIMENTAL TESTS}

The research presented in the article was conducted on a selected tram line section, on which two different types of slab track were used [10]. It included a section made using the anchor rail system (AR) with point support of rail tracks and a section made using the Rheda-City system (RC) covered with a layer of humus with vegetation [15]. Experimental research was performed in close proximity to where both types of track connect, simultaneously recording noise and paraseismic vibrations.

\subsection{FIELD TESTS}

The tests were performed at two measuring points arranged as follows:

- paraseismic vibration measurement point 1 (further referred to as AR) was located $3.2 \mathrm{~m}$ from the center of the anchor rail type track,

- paraseismic vibration measurement point 2 (further referred to as RC) was located $3.2 \mathrm{~m}$ from the center of the Rheda City type track,

The distance between measuring points 1 and 2 was $15 \mathrm{~m}$. konstrukcję tramwaju i toru, przy czym największe wartości przyjmują w zakresach częstotliwości mniejszych niż $50 \mathrm{~Hz}$, a dla wyższych częstotliwości wraz z ich wzrostem coraz szybciej zanikają. W zakresach 30-2000 Hz dominuje hałas związany bezpośrednio z ruchem tramwaju, przy czym dla wyższych częstotliwości energia procesu wibroakustycznego jest propagowana do otoczenia głównie przez koła i szyny [14].

Hałas i drgania generowane ruchem tramwajów można sklasyfikować jako oddziaływania krótkotrwałe, przejściowe [8]. Biorąc pod uwagę uciążliwość tego typu oddziaływań, należy również zauważyć, że sieć linii tramwajowych jest znacznie mniejsza niż sieć uliczna, w związku z tym populacja mieszkańców narażonych na oddziaływania wibroakustyczne powodowane ruchem tramwajów jest znacznie mniejsza niż ogólna liczba narażonych mieszkańców obszaru miejskiego $[2,12]$. Poziom głośności hałasu generowanego przez przejazd tramwaju zależy od konstrukcji toru ze względu na rodzaj użytych podkładów, zamocowania szyn, rodzaj toru i rodzaj podłoża i podłoża [13]. $\mathrm{Na}$ amplitudę generowanych interakcji ma wpływ lokalizacja toru, gdyż występują duże różnice dla przebiegu linii na mostach, tunelach oraz w poziomie terenu, ale niezaprzeczalnie duży wpływ ma także poziom utrzymania podłoża, szyny i podkładów [9]. W przypadku badanej grupy pojazdów szynowych jednostki napędowe i właściwości aerodynamiczne pojazdów miały niewielki wpływ na generowane przez nie oddziaływania. Ze względu na długość okresów narażenia mieszkańców, oddziaływania opisywane w pracy są stosunkowo krótkie, stąd nie można ich uznać za szkodliwe, ale raczej za uciążliwe.

\section{BADANIA EKSPERYMENTALNE}

Badania przedstawione $\mathrm{w}$ artykule prowadzone były na wybranym odcinku linii tramwajowej, na którym występuje torowisko wykonane w dwóch różnych rodzajach nawierzchni bezpodsypkowej [10]. Znalazły się tu odcinek wykonany w systemie szyny kotwionej (AR) $\mathrm{z}$ punktowym podparciem toków szynowych oraz odcinek wykonany w systemie Rheda-City (RC) pokryty warstwą humusu z porostem roślinnym [15]. Badania eksperymentalne prowadzono w bliskim otoczeniu połączenia obu typów nawierzchni, rejestrując jednocześnie drgania parasejsmiczne $i$ hałas.

\subsection{POLIGON BADAWCZY}

Badania prowadzono $\mathrm{w}$ dwóch punktach pomiarowych rozmieszczonych następująco:

- punkt pomiarowy drgań parasejsmicznych nr 1 (oznaczony dalej w pracy AR) umieszony był w odległości 3,2 m od linii osi toru wykonanego w systemie szyny kotwionej

- punkt pomiarowy drgań parasejsmicznych $\mathrm{nr} 2$ (oznaczony dalej w pracy RC) umieszony był w 
Vibration acceleration characteristics were recorded at selected points using data acquisition equipment which included accelerometers with a sensitivity of 1 $\mathrm{V} / \mathrm{g}$, ICP signal amplifiers, a 16-channel NI transducer card and a portable computer as a time characteristics and analyzer.

It should be noted that the high sensitivity of piezoelectric transducers gives them the ability to diagnose low amplitudes of measured vibrations. Taking into account the Nyquist frequency criterion, in order to avoid the aliasing phenomenon (irreversible distortion of the signal), the sampling frequency should be at least twice as high as the highest frequency at which diagnosis is necessary [8]. In the experimental studies carried out, the following set of signal registration parameters was adopted:

$$
\left\{\begin{array}{l}
f_{\text {max }}=512[\mathrm{~Hz}] \stackrel{\text { zkryterium Nyquista }}{\longrightarrow} f_{\text {p min }}=1024[\mathrm{~Hz}] \\
N s=\frac{f_{p \min }}{d_{f}}=8192\left[\text { próbki] } \stackrel{\text { czas rejestracji }}{\longrightarrow} t_{\text {min }}=8[\mathrm{~s}]\right. \\
\text { przy } d_{f}=0,125[\mathrm{~Hz}],
\end{array}\right.
$$

where:

$f_{\max }$ - the highest frequency which needs to be reproduced,

$f_{p \text { min }}-$ the lowest sampling frequency of the recorded signal,

$d_{f}$ - the minimum frequency resolution of the signal (most important for frequencies close to $1 \mathrm{~Hz}$ ),

$N_{s}$ - the minimum number of signal samples to register,

$t_{\min }$ - the minimum recording time for a given sampling frequency.

\subsection{METHOD OF RESULTS ANALYSIS}

The recorded vibration acceleration signals were analyzed in time and frequency domains. Wavelet transformation was used to achieve this, the main element of which are the so-called basic wavelets $\psi$ functions with zero average value and compact carrier and families of these wavelets, which are created by "moving" $(d)$ and "stretching" $(s)$ of the basic wavelet $[8,16]$ :

$$
\psi_{s d}(t)=\frac{1}{\sqrt{s}} \psi\left(\frac{t-d}{s}\right)
$$

The scale factor represents the iteration at which the frequency of the wavelet will be obtained. The wavelet transform is defined according to the equation (3):

$$
\widetilde{S}_{\psi}(s, d)=\frac{1}{\sqrt{s}} \int_{-\infty}^{\infty} u(t) \psi^{*}\left(\frac{t-d}{s}\right) d t,
$$

odległości 3,2 m od linii osi toru wykonanego w systemie Rheda City.

Odległość między punktami pomiarowymi 1 i 2 wynosiła $15 \mathrm{~m}$.

W wytypowanych punktach rejestrowano przebiegi przyspieszenia drgań, z zastosowaniem aparatury do akwizycji danych, złożonej z akcelerometrów o czułości $1 \mathrm{~V} / \mathrm{g}$, wzmacniaczy sygnału ICP, 16-kanałowej karty przetwornika NI oraz komputera przenośnego, jako rejestratora przebiegów czasowych i analizatora.

Należy zauważyć, że wysoka czułość przetworników piezoelektrycznych wpływa na możliwość diagnozowania niskich amplitud mierzonych drgań. Biorąc pod uwagę kryterium częstotliwościowe Nyquista, w celu uniknięcia zjawiska aliasingu (nieodwracalnego zniekształcenia sygnału), częstotliwość próbkowania powinna być co najmniej dwukrotnie wyższa niż najwyższa częstotliwość, dla której zaistnieje konieczność diagnozowania [8]. W prowadzonych badaniach eksperymentalnych przyjęto następujący układ parametrów rejestracji sygnałów:

$$
\left\{\begin{array}{l}
f_{\max }=512[\mathrm{~Hz}] \stackrel{\text { z kryterium Nyquista }}{\longrightarrow} f_{p \min }=1024[\mathrm{~Hz}] \\
N s=\frac{f_{p \min }}{d_{f}}=8192\left[\text { próbki] } \stackrel{\text { czas rejestracji }}{\longrightarrow} t_{\min }=8[\mathrm{~s}]\right. \\
\operatorname{przy}_{f}=0,125[\mathrm{~Hz}],
\end{array}\right.
$$

gdzie:

$f_{\max }-\quad$ najwyższa częstotliwość, dla której zaistnieje konieczność odtworzenia,

$f_{p \min }-$ najmniejsza częstotliwość próbkowania rejestrowanego sygnału,

$d_{f}$ - minimalna rozdzielczość częstotliwościowa sygnału (największe znaczenie dla częstotliwości bliskich $1 \mathrm{~Hz}$ ),

$N_{s}-$ minimalna liczba próbek sygnału do zarejestrowania,

$t_{\text {min }}-\quad$ minimalny czas rejestracji dla zadanej częstotliwości próbkowania.

\subsection{METODA ANALIZY OTRZYMANYCH WY- NIKÓW BADAŃ}

Zarejestrowane sygnały przyspieszenia drgań poddawano analizie w dziedzinie czasu i częstotliwości. $\mathrm{W}$ tym celu wykorzystano przekształcenie falkowe, którego podstawowym elementem są tzw. falki podstawowe $\psi$ - funkcje o zerowej wartości średniej i zwartym nośniku oraz rodziny tych falek, które tworzone są przez ,przesuwanie” (d) i „rozciaganie” $(s)$ falki podstawowej $[8,16]$ :

$$
\psi_{s d}(t)=\frac{1}{\sqrt{s}} \psi\left(\frac{t-d}{s}\right)
$$


where:

$S \quad-$ scale factor (responsible for the frequency represented by the adopted wavelet function, with its increase the frequency decreases),

$D$ - offset coefficient,

$u(t)$ - the analyzed signal,

$\Psi \quad-$ wavelet function.

The studies used a continuous wavelet transform (CWT in the Matlab environment) presented below [ $1,6,16]$ :

$$
\operatorname{CTF}_{s}^{t}(s, d)=\frac{1}{\sqrt{s}} \int_{-\infty}^{\infty} u(t) \psi^{*}\left(\frac{t-d}{s}\right) d t .
$$

The signal was decomposed using the Morlet wavelet, which is shown in Figure 1.

The use of wavelet transform enables observation and analysis of non-stationary signals, which allows for quick detection of non-linearities in vibration propagation paths.

\subsection{EVALUATION CRITERIA FOR OBTAINED TEST RESULTS}

The indicator method was used to assess the obtained test results in the frequency domain. A universal Vibration Load Factor ${ }^{l}$ was used, calculated according to (5), using acceleration amplitude (aa), independently for each direction of vibration interaction and each octave frequency band from the spectrum of the analyzed frequencies [7].

$$
\forall \underset{f \in F_{t}}{\forall} \forall \in D L F_{a a k}=\frac{a_{k}(f)}{a_{k d o p}(f)},
$$

where:

$f \quad$ - mid-frequency of the octave band [Hz],

$F_{t} \quad$ - vector of the middle frequency octave

bands $\operatorname{dim} F_{t}=1 \times n$

- when calculating the impact of vibrations on

people $n=20$,

- when calculating the impact of vibrations on

a building structure $n=21$,

$k-$ direction of vibrations,

$D \quad-$ a set of analyzed directions of the effect,

$a_{k} \quad$ - value of the vibration acceleration predicted or measured in experimental research in the direction $k\left[\mathrm{~m} / \mathrm{s}^{2}\right]$,

$a_{k d o p}-$ the permissible limit value of the vibration acceleration for the selected octave band $\left[\mathrm{m} / \mathrm{s}^{2}\right]$ defined as:

$$
a_{k d o p}=\left\{\begin{array}{l}
a_{k_{-} r m s} \\
a_{k_{-} \max }
\end{array}\right.
$$

Współczynnik skali reprezentuje iterację, w której uzyskana zostanie częstotliwość falki. Transformata falkowa definiowana jest wg zależności (3):

$$
\widetilde{S}_{\psi}(s, d)=\frac{1}{\sqrt{s}} \int_{-\infty}^{\infty} u(t) \psi^{*}\left(\frac{t-d}{s}\right) d t,
$$

gdzie:

$S \quad-$ współczynnik skali (odpowiedzialny za częstotliwość reprezentowaną przez przyjętą funkcję falkową, z jego wzrostem częstotliwość maleje),

$D \quad$ - współczynnik przesunięcia,

$u(t)$ - analizowany sygnał,

$\Psi$ - funkcja falkowa.

W badaniach wykorzystano ciagłą transformate falkowa (CWT w środowisku Matlab) przedstawiona poniżej $[1,6,16]$ :

$$
\operatorname{CTF}_{s}^{t}(s, d)=\frac{1}{\sqrt{s}} \int_{-\infty}^{\infty} u(t) \psi^{*}\left(\frac{t-d}{s}\right) d t .
$$

Dekompozycji sygnału dokonywano $\mathrm{z}$ wykorzystaniem falki Morlet, której przebieg pokazano na rysunku 1.

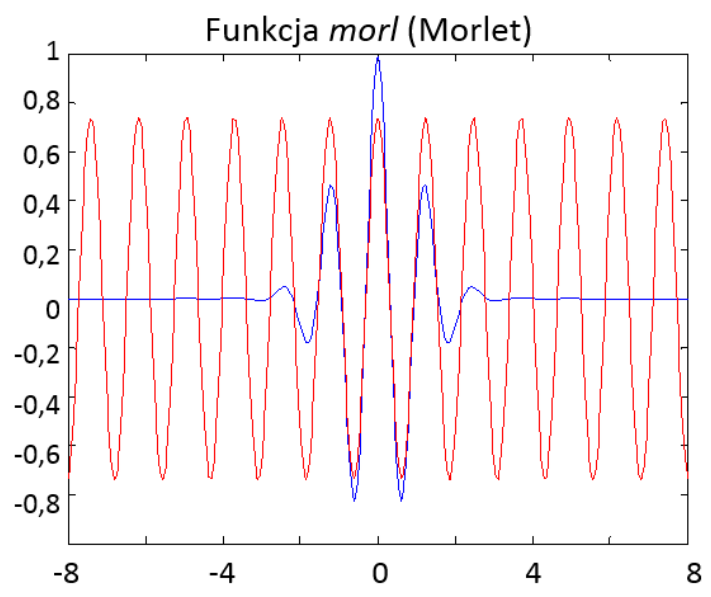

Fig. 1. The used Morlet wavelet function

Rys. 1. Przebieg wykorzystanej funkcji falkowej Morlet

Wykorzystanie transformaty falkowej umożliwia obserwację i analizę sygnałów niestacjonarnych, co pozwala na szybkie wykrywanie nieliniowości w ścieżkach propagacji drgań.

\subsection{KRYTERIA OCENY OTRZYMANYCH WYNIKÓW BADAŃ}

Do oceny otrzymanych wyników badań w dziedzinie częstotliwości zastosowano metodę wskaźnikowa. Wykorzystano uniwersalny wskaźnik obciążenia drganiami (ang. Vibration Load Factor ${ }^{l}$ ) obliczany wg zależności (5), z wykorzystaniem amplitud przyspieszeń (aa - ang. acceleration amplitude), niezależnie dla każdego kierunku oddziaływania drgań i każdego pasma tercjowego $\mathrm{z}$ widmie analizowanych częstotliwości [7]. 
$a_{k \_r m s}-$ threshold of human perception of vibrations in the direction $k$, in accordance with PN-B-02171:2017-06,

$a_{k_{-} \max }-$ the limit of allowed vibration acceleration values - the value of vibration acceleration lower limit in the direction $k$ that is considered for the dynamic impact on buildings according to PN-B-02170:2016-12.

The indicators are calculated analogically for all vibration directions or evaluation of the impact of vibrations on the building construction, excluding the rms. values in the case of calculating the impact of vibrations on physical structures. In addition, logarithmic indicators were determined as described by (7).

$$
V L F_{\text {aakl }}=20 \log V L F_{\text {aak }} \quad .
$$

The use of logarithmic indicators allows obtaining a much "faster response" of the indicator relative to the traditional method of using vibration to determine the load.

To assess the impact of the generated noise, a variable was used that characterized the overall load condition using dynamic effects, which also provides direct information on potential exposure [8]. The harmfulness of transport means was determined for the analyzed measurement points as well as at a distance close to the location of physical structures. The scalar physical quantity, denoting the noise impact value at this point, was determined as described by relation (8). The reference level for determining the potential difference between this point and any point belonging to the area covered by the analysis of dynamic interactions, in which the potential is zero, is the lowest limit value of the assessed physical quantity indicated by the standards ${ }^{2}$.

$$
P S O_{S T}=\left\{\begin{array}{l}
0, \text { dla } V L F[\mathrm{~dB}]<0 \\
1, \text { dla } 0 \leq V L F[\mathrm{~dB}]<L_{A}, \\
2, \text { dla } L_{A} \leq V L F[\mathrm{~dB}]
\end{array}\right.
$$

where $L_{A}$ is the upper limit of the acceptable level, and depends on the limit value under the adopted measurement conditions, i.e. depending on the intended purpose of the structures and spaces located within the dynamic effects range.

The results obtained were referred to the PN-B02171:2017-06 standard, which specifies the methods for assessing the impact of vibrations transmitted to people residing in buildings, and an interpretation of the harmful noise impact level ranges in the form of criteria scales based on [8] was adopted for various purpose buildings and structures.

\footnotetext{
2 for example for the purpose of assessing the impact of vibrations on humans, the limit value of human vibration is the human sensory threshold value.
}

$$
\forall \underset{f \in F_{t}}{\forall} \forall \in D L F_{a a k}=\frac{a_{k}(f)}{a_{k d o p}(f)},
$$

gdzie:

$f \quad$ - częstotliwość środkowa pasma tercjowego $[\mathrm{Hz}]$,

$F_{t} \quad$-wektor częstotliwości środkowych pasm tercjowych $\operatorname{dim} F_{t}=1 \times n$

- w przypadku obliczania wpływu drgań na ludzi $n=20$,

- dla wpływu drgań na obiekt inżynierski $n=$ 21 ,

$k \quad$ - kierunek oddziaływania drgań,

$D$ - zbiór analizowanych kierunków oddziaływania,

$a_{k} \quad$ - wartość prognozowanego lub pomierzonego $\mathrm{w}$ badaniach eksperymentalnych przyspieszenia drgań w kierunku $k\left[\mathrm{~m} / \mathrm{s}^{2}\right]$,

$a_{k d o p}$ - wartość dopuszczalna przyspieszenia drgań dla wybranego pasma tercjowego $\left[\mathrm{m} / \mathrm{s}^{2}\right]$ wg zależności:

$$
a_{k d o p}=\left\{\begin{array}{l}
a_{k \_r m s} \\
a_{k \_ \text {max }}
\end{array}\right.
$$

$a_{k_{-} r m s}-$ próg odczuwalności przez człowieka drgań $\mathrm{w}$ kierunku $k$, zgodnie $\mathrm{z}$ normą PN-B02171:2017-06,

$a_{k \_\max }-$ wartość dopuszczalna przyspieszenia drgań - wartość przyspieszenia drgań określająca dolną granicę uwzględniania wpływów dynamicznych na budynek w kierunku $k$ zgodnie z normą PN-B-02170:2016-12.

Wskaźniki liczone są analogicznie dla wszystkich kierunków oddziaływania drgań lub oceny wpływu drgań na konstrukcję obiektu, z wyłączeniem wartości rms. w przypadku obliczania wpływu drgań na konstrukcje inżynierskie. Dodatkowo wyznaczono logarytmiczne wskaźniki zgodnie z zależnością (7).

$$
V L F_{\text {aakl }}=20 \log V L F_{\text {aak }}
$$

Wykorzystanie wskaźników logarytmicznych pozwala na uzyskanie znacznie „szybszej reakcji” wskaźnika w stosunku do tradycyjnej metody wyznaczania wskaźnika obciążenia drganiami.

Do oceny wpływu generowanych oddziaływań wykorzystano wielkość charakteryzującą ogólny stan obciążenia oddziaływaniami dynamicznymi, która bezpośrednio informuje o ewentualnym narażeniu [8]. Poziom szkodliwości oddziaływań środków transportu wyznaczano dla analizowanych punktów pomiarowych oraz w odległości bliskiego usytuowania obiektów inżynierskich. Skalarna wielkość fizyczna, oznaczająca wartość oddziaływania w tym punkcie wyznaczana była zgodnie $\mathrm{z}$ zależnością (8). Poziomem odniesienia do wyznaczenia różnicy potencjałów pomiędzy tym punktem a dowolnym punktem nale- 


\subsection{IMPACT OF GROUND DAMPING}

In cases of modeling vibrations propagation in the ground, a wide range of simplifications has been adopted. Based on the results of experimental research conducted by various scientific and research centers [3], which confirm the possibility of adopting certain simplifying assumptions, for any geological substrate $(\alpha)$ and at any distance $(r)$ from the original measurement point $\left(r_{0}\right)$, in which vibrations were recorded taking into account the geometric suppression and the soil absorption index $(w)$ the approximate amplitude of the surface vibration wave can be determined as:

where:

$$
\frac{a_{i}}{a_{0}}=\left(\frac{r_{0}}{r_{i}}\right)^{w} e^{-\alpha\left(r_{i}-r_{0}\right)}
$$

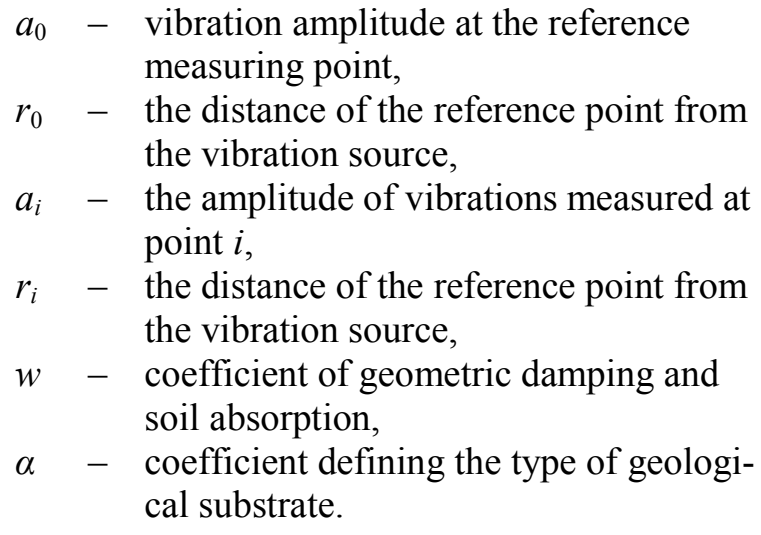

The studies assumed the soil parameters corresponding to the hydrogeological conditions typical for Warsaw (sandy loams and silty sands).

\section{RESULTS}

The results were divided into two groups, one obtained as a result of CWT and the other as a result of calculations based on indicators.

\subsection{MULTI-RESOLUTION ANALYSIS OF SIG- NALS}

Figures $2 \div 7$ present the results of vibration accelerations measurements and wavelet transformations of the analyzed signals. At the measuring points for the anchor rail system, with point support of rail tracks, the charts were marked with the AR index, while the results obtained on the section made in the Rheda-City system covered with a layer of humus with vegetation were marked as RC.

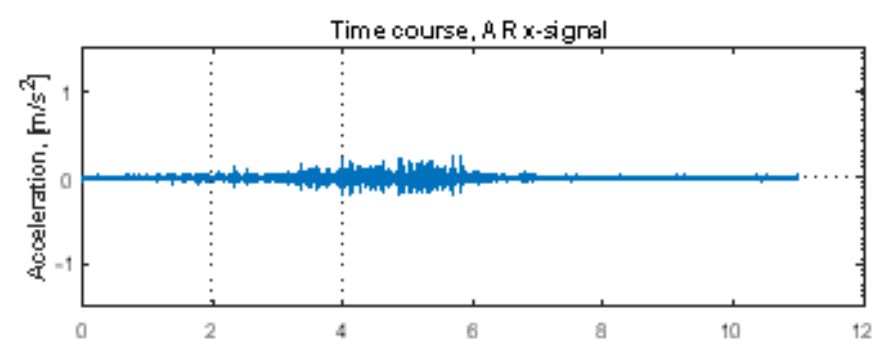

żącym obszaru objętego analizą oddziaływań dynamicznych, w którym potencjał wynosi zero, jest najniższa graniczna wartość ocenianej wielkości fizycznej wskazywanej przez normy ${ }^{2}$

$$
P S O_{S T}=\left\{\begin{array}{l}
0, \text { dla } V L F[\mathrm{~dB}]<0 \\
1, \text { dla } 0 \leq V L F[\mathrm{~dB}]<L_{A}, \\
2, \text { dla } L_{A} \leq V L F[\mathrm{~dB}]
\end{array},\right.
$$

gdzie $L_{A}$ oznacza górną granicę poziomu akceptowalnego, zależną od wartości dopuszczalnej w przyjętych warunkach pomiaru, np. zależna od przeznaczenia pomieszczeń obiektu inżynierskiego zlokalizowanego w strefie wpływów dynamicznych.

Otrzymywane wyniki odnoszono do zapisów normy PN-B-02171:2017-06, w której określono metody oceny wpływu drgań przekazywanych na ludzi przebywających w budynkach, a na podstawie pracy [8] przyjęto interpretację zakresów wartości poziomu szkodliwości oddziaływań w postaci skal kryterialnych dla obiektów inżynierskich o różnym przeznaczeniu.

\subsection{WPLYW TLUMIENIA GRUNTU}

$\mathrm{W}$ przypadkach modelowania propagacji drgań $\mathrm{w}$ podłożu przyjęto daleko idące uproszczenia. Opierając się na wynikach badań eksperymentalnych prowadzonych przez różne ośrodki naukowo-badawcze [8], które potwierdzają możliwość przyjęcia pewnych założeń upraszczających, dla dowolnego podłoża geologicznego $(\alpha)$ i w dowolnej odległości $(r)$ od pierwotnego punktu pomiarowego $\left(r_{0}\right)$, w którym zarejestrowano drgania, przy uwzględnieniu thumienia geometrycznego i wskaźnika absorpcji gruntu (w) można wyznaczyć przybliżoną amplitudę powierzchniowej fali drganiowej:

gdzie:

$$
\frac{a_{i}}{a_{0}}=\left(\frac{r_{0}}{r_{i}}\right)^{w} e^{-\alpha\left(r_{i}-r_{0}\right)}
$$

$a_{0} \quad-\quad$ amplituda drgań $\mathrm{w}$ referencyjnym punkcie pomiarowym,

$r_{0} \quad-\quad$ odległość punktu referencyjnego od źródła drgań,

$a_{i} \quad-\quad$ amplituda drgań zmierzonych w punkcie

$i$

$r_{i}-$ odległość punktu referencyjnego od źródła drgań,

$w$ - współczynnik thumienia geometrycznego i absorpcji gruntu,

$\alpha$ - współczynnik definiujący rodzaj podłoża geologicznego.

W badaniach przyjęto parametry gruntu odpowiadających warunkom hydrogeologicznym typowym dla Warszawy (gliny piaszczyste i piaski pylaste).

np. dla potrzeb dokonania oceny oddziaływania drgań na człowieka, graniczną wartością jest próg odczuwalności drgań przez człowieka. 


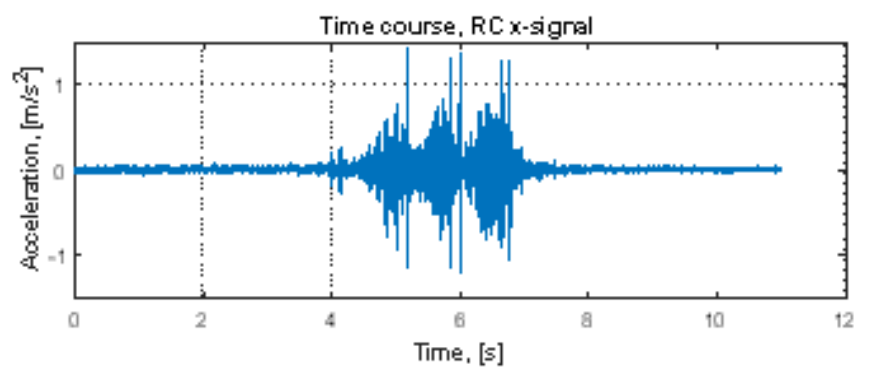

Fig. 2. Waveforms of recorded vibration accelerations in the longitudinal direction $-\mathrm{x}$

Rys. 2. Przebiegi zarejestrowanych przyspieszeń drgań w kierunku wzdłużnym - $\mathrm{x}$

Figure 3 shows the result of the calculated continuous wavelet transform for vibration accelerations in the longitudinal direction.
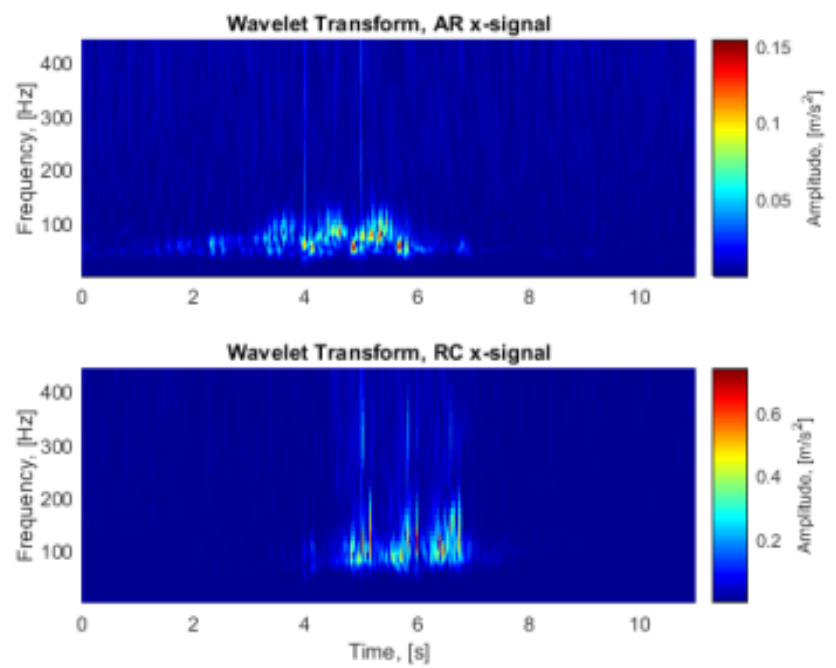

Fig. 3. Frequency-time analysis of vibrations generated in the longitudinal direction $-\mathrm{x}$

Rys. 3. Analiza częstotliwościowo-czasowa drgań generowanych w kierunku wzdłużnym - $\mathrm{x}$

Figure 4 shows the time characteristic of vibration accelerations in the transverse direction.

Figure 5 shows the calculation result of a continuous wavelet transform for vibration acceleration in the transverse direction.
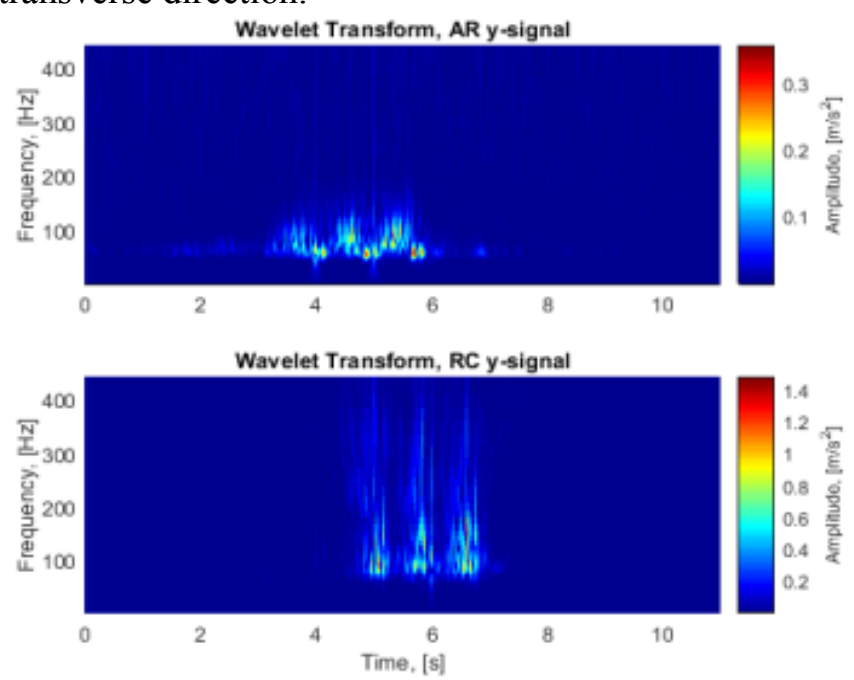

Fig. 5. Frequency-time analysis of vibrations generated in the transverse direction - $y$

Rys. 5. Analiza częstotliwościowo-czasowa drgań generowanych w kierunku poprzecznym - y

\section{WYNIKI BADAŃ}

Przykładowe wyniki badań podzielono na grupe rezultatów otrzymanych w wyniku CWT oraz wyniki obliczeń wskaźnikowych.

\subsection{ANALIZA WIELOROZDZIELCZA SYGNA- LÓW}

Na rysunkach $2 \div 7$ przedstawiono wyniki pomiarów przyspieszeń drgań oraz przekształcenia falkowego analizowanych sygnałów. W punktach pomiarowych dla systemu szyny kotwionej, z punktowym podparciem toków szynowych wykresy oznaczano indeksem $\mathrm{AR}$, natomiast wyniki uzyskane na odcinku wykonanym w systemie Rheda-City, pokrytego warstwą humusu z porostem roślinnym, oznaczano odpowiednio RC.

$\mathrm{Na}$ rysunku 4 przedstawiono przebieg czasowy przyspieszeń drgań w kierunku poprzecznym.
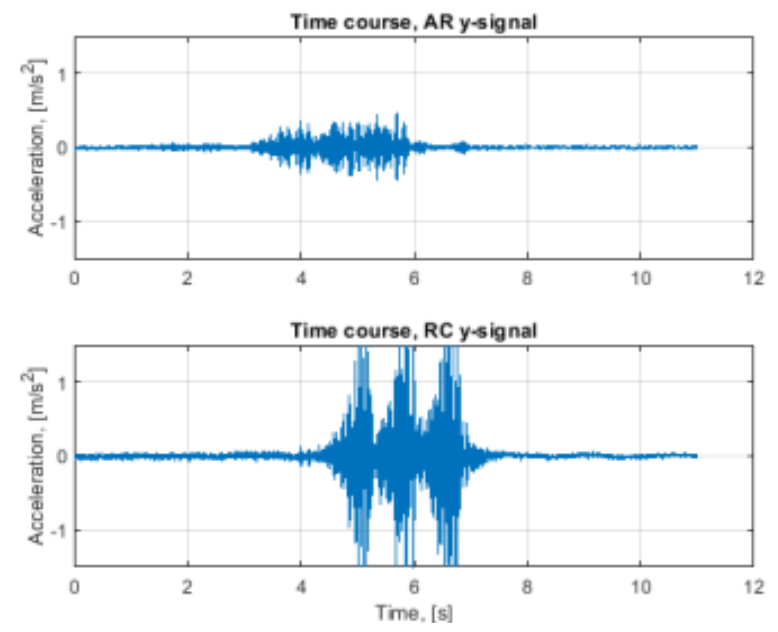

Fig. 4. The waveforms of recorded vibration accelerations in the transverse direction - $y$

Rys. 4. Przebiegi zarejestrowanych przyspieszeń drgań w kierunku poprzecznym - y

Na rysunku 5 przedstawiono wynik obliczenia ciagłej transformaty falkowej dla przyspieszeń drgań w kierunku poprzecznym.
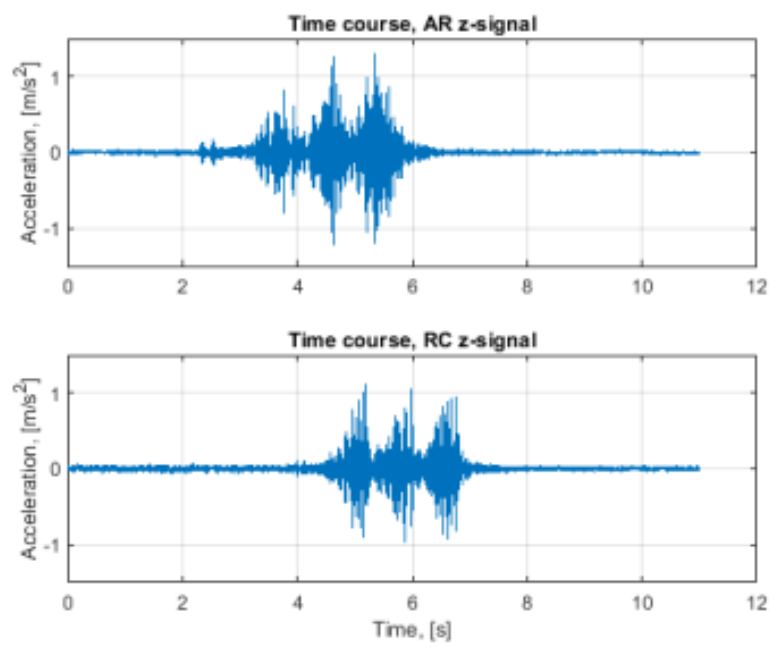

Fig. 6. Waveforms of recorded vibration accelerations in the vertical direction - $\mathrm{z}$

Rys. 6. Przebiegi zarejestrowanych przyspieszeń drgań w kierunku pionowym - z 
Figure 6 shows the characteristic of vibration accelerations in the vertical direction.

Figure 7 shows the calculation result of a continuous wavelet transform for vibration accelerations in the vertical direction.
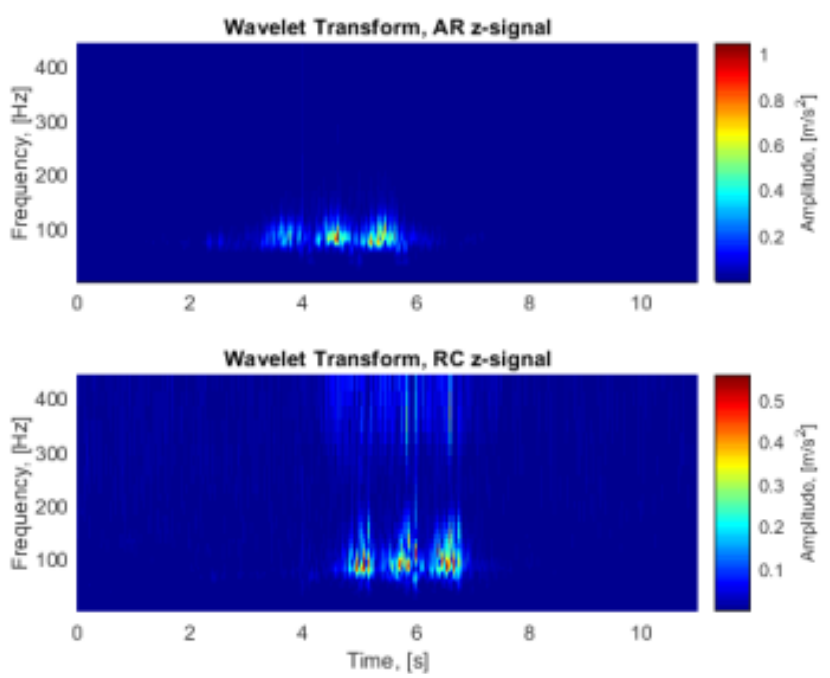

Fig. 7. Frequency-time analysis of vibrations generated in the vertical direction - $\mathrm{z}$

Rys. 7. Analiza częstotliwościowo-czasowa drgań generowanych w kierunku pionowym - z

\subsection{INDICATOR METHOD - VIBRATION LOAD COEFFICIENT}

Tables $1 \div 2$ present the calculation results of vibration load factors $V L F$, according to (4) for people present in buildings and structures $\left(V L F_{a a x-y-z}\right)$ and for the assessment of impacts on the construction $V L F_{b}$ of buildings. Their logarithmic versions, whose indexes were preceded by the letter $l$, were also presented. The location of objects at a distance of $10 \mathrm{~m}$ from the measurement points was adopted in the calculations.

Vibration acceleration values in octave bands and calculated vibration load factors for people and buildings, at the $\mathrm{RC}$ measurement point Table 2

Wartości przyspieszenia drgań w pasmach tercjowych oraz obliczone wspólczynniki obciążenia drganiami dla ludzi oraz obiektów inżynierskich, w punkcie pomiarowym RC

Tablica 2

For the obtained results of $V L F$ indicators, the level of harmfulness (PSO) was determined in each case according to the relationship (7). The resulting values did not exceed the value of 0 in any of the analyzed cases, hence there is no basis for stating that in any of the analyzed cases there was a harmful impact of communication vibrations, at a distance of $10 \mathrm{~m}$ from the measurement points.

\section{CONCLUSIONS}

The impact of a tramway track segment that has been in continuous operation for over a 5-year period was analyzed in the article. The measurement section was subject to observation in the period following its modernization to the point when the measurements
Na rysunku 6 przedstawiono przebieg czasowy przyspieszeń drgań w kierunku pionowym.

\subsection{METODA WSKAŹNIKOWA - WSPÓL- CZYNNIK OBCIĄŻENIA DRGANIAMI}

W tablicach $1 \div 2$ przedstawiono wyniki obliczeń współczynników obciążenia drganiami $V L F$, zgodnie z zależnością (4) dla ludzi przebywających w obiektach inżynierskich $\left(V L F_{a a x-y z z}\right)$ oraz dla oceny oddziaływań na konstrukcje obiektów inżynierskich $V L F_{b}$. Przedstawiono również ich wersje logarytmiczne, których indeksy poprzedzono literą $l$. W obliczeniach przyjęto lokalizację obiektów w odległości $10 \mathrm{~m}$ od punktów pomiarowych.

Vibration acceleration values in octave bands and calculated vibration load factors for people and buildings, at the AR measurement point

Table 1

Wartości przyspieszenia drgań w pasmach tercjowych oraz obliczone współczynniki obciążenia drganiami dla ludzi oraz obiektów inżynierskich, punkcie pomiarowym AR Tablica 1

\begin{tabular}{|c|c|c|c|c|c|c|c|c|c|}
\hline f & ax & ay & $\mathbf{a z}$ & $\mathbf{V L F}_{\text {aaxy }}$ & $\mathbf{V L F}_{\text {aaz }}$ & $\mathbf{V L F}_{\mathrm{b}}$ & $\mathbf{V L F}_{\text {aalxy }}$ & $\mathbf{V L F}_{\text {aalz }}$ & $\mathbf{V L F}_{\mathbf{I} b \mathbf{b}}$ \\
\hline [Hz] & \multicolumn{3}{|c|}{$\left[\mathrm{m} / \mathbf{s}^{2}\right]$} & \multicolumn{3}{|c|}{$\left[\mathbf{m} / \mathbf{s}^{2} / \mathbf{m} / \mathbf{s}^{2}\right]$} & \multicolumn{3}{|c|}{$[\mathrm{dB}]$} \\
\hline 1,00 & 0,0008 & 0,0002 & 0,0003 & 0,23 & \begin{tabular}{|l|}
0,03 \\
\end{tabular} & 0,03 & $-12,68$ & $-31,62$ & $-29,52$ \\
\hline 1,25 & 0,0004 & 0001 & 0,0012 & 12 & 0,14 & 0,02 & $-18,14$ & $-17,12$ & $-34,98$ \\
\hline 1,60 & 0,0005 & 0,0001 & 0,0015 & 15 & 0,19 & 0,02 & $-16,53$ & $-14,37$ & $-33,36$ \\
\hline 2,00 & 0,0006 & 0,0002 & 0,0011 & 16 & 0,16 & 0,02 & $-15,70$ & $-15,76$ & $-32,53$ \\
\hline 2,50 & 0,0006 & 0,0005 & 0,0003 & 13 & 0,05 & 0,02 & $-17,75$ & $-25,95$ & $-32,65$ \\
\hline 3,15 & 0,0006 & 0,0006 & 0,0007 & & 0,12 & 0,03 & $-19,17$ & $-18,21$ & $-32,02$ \\
\hline 4,00 & 0,0004 & 0,0003 & 0,0003 & & 0,07 & 0,02 &, 12 & & 5,93 \\
\hline 5,00 & 0,0013 & 0,0005 & 0,0013 & 14 & 0,26 & 0,05 & $-16,95$ &, 68 & $-25,82$ \\
\hline 6,30 & 0,0018 & 0,0006 & 0,0013 & 16 & 0,26 & 0,07 & $-16,04$ & $-11,79$ & $-22,87$ \\
\hline 8,00 & 0,0005 & 0,0014 & & & 0,14 & 0,05 & $-20,29$ & $-17,08$ & $-26,37$ \\
\hline 10,00 & 0,0005 & 0,0011 & 0,0006 & 06 & 0,09 & 0,03 & $-24,07$ & $-20,56$ & $-29,59$ \\
\hline 12,50 & 0,0007 & 0,0003 & 0,0009 & & 0,11 & 0,02 & $-30,36$ & $-18,82$ & $-35,14$ \\
\hline 16,00 & 0,0002 & 0,0012 & & & 0,11 & 0,03 & $-27,87$ & $-19,17$ & $-31,90$ \\
\hline 20,00 & 0,0008 & 0,0012 & 0,0015 & 0,03 & 0,12 & 0,02 & $-29,54$ & $-18,20$ & $-32,88$ \\
\hline 25,00 & 0,0015 & 0,0009 & 0,0011 & 0,03 & 0,07 & 0,02 & $-29,44$ & $-23,13$ & $-32,21$ \\
\hline 31,50 & 0,0014 & 0,0018 & 0,0008 & 0,03 & 0,04 & 0,03 & $-29,97$ & $-27,41$ & $-32,03$ \\
\hline 40,00 & 0,0046 & 0,0021 & 0,0012 & 0,06 & 0,05 & 0,06 & $-23,88$ & $-26,43$ & $-25,10$ \\
\hline 50,00 & 0,0052 & 0,0012 & 0,0010 & 0,06 & 0,03 & 0,05 & $-24,76$ & $-30,29$ & $-25,30$ \\
\hline 63,00 & 0,0014 & 0,0041 & 0,0052 & 0,04 & 0,13 & 0,04 & $-28,84$ & $-17,54$ & $-28,53$ \\
\hline 80,00 & 0,0020 & 0,0039 & 0,0054 & 0,03 & 0,11 & 0,03 & $-31,37$ & $-19,39$ & $-30,48$ \\
\hline 100,00 & 0,0006 & 0,0033 & 0,0013 & 0,02 & 0,02 & 0,02 & $-34,39$ & $-33,35$ & $-33,23$ \\
\hline \multicolumn{4}{|c|}{ Maksimum } & 0,23 & 0,26 & 0,07 & $-12,68$ & $-11,68$ & $-22,87$ \\
\hline
\end{tabular}

Table 2 Tablica 2

\begin{tabular}{|c|c|c|c|c|c|c|c|c|c|}
\hline f & $\mathbf{a x}$ & ay & $\mathbf{a z}$ & $\mathbf{V L F}_{\text {aaxy }}$ & $\mathbf{V L F}_{\text {aaz }}$ & $\mathbf{V L F}_{\mathrm{b}}$ & $\mathbf{V L F}_{\text {aalxy }}$ & $\mathbf{V L F}_{\text {aalz }}$ & $\mathbf{V L F}_{1 \mathrm{~b}}$ \\
\hline$[\mathrm{Hz}]$ & \multicolumn{3}{|c|}{$\left[\mathbf{m} / \mathbf{s}^{2}\right]$} & \multicolumn{3}{|c|}{$\left[\mathbf{m} / \mathbf{s}^{2} / \mathbf{m} / \mathbf{s}^{2}\right]$} & \multicolumn{3}{|c|}{$[\mathrm{dB}]$} \\
\hline 1,00 & 0,0005 & 0,0013 & 0,0012 & 0,37 & 0,12 & 0,05 & $-8,66$ & $-18,27$ & $-25,49$ \\
\hline 1,25 & 0,0004 & 0,0006 & 0,0007 & 0,17 & 0,07 & 0,02 & $-15,64$ & $-22,56$ & $-32,47$ \\
\hline 1,60 & 0,0010 & 0,0003 & 0,0004 & 0,29 & 0,05 & 0,04 & $-10,70$ & $-26,78$ & $-27,54$ \\
\hline 2,00 & 0,0012 & 0,0006 & 0,0005 & 0,33 & 0,07 & 0,05 & $-9,55$ & $-22,57$ & $-26,39$ \\
\hline 2,50 & 0,0005 & 0,0003 & 0,0006 & 0,11 & 0,09 & 0,02 & $-19,30$ & $-21,01$ & $-34,19$ \\
\hline 3,15 & 0,0010 & 0,0002 & 0,0005 & 0,17 & 0,09 & 0,04 & $-15,38$ & $-20,92$ & $-28,23$ \\
\hline 4,00 & 0,0012 & 0,0002 & 0,0009 & 0,16 & 0,17 & 0,05 & $-15,88$ & $-15,35$ & $-26,69$ \\
\hline 5,00 & 0,0004 & 0,0002 & 0,0010 & 0,04 & 0,20 & 0,02 & $-27,12$ & $-13,99$ & $-36,00$ \\
\hline 6,30 & 0,0012 & 0,0006 & 0,0012 & 0,11 & 0,23 & 0,05 & $-19,56$ & $-12,76$ & $-26,38$ \\
\hline 8,00 & 0,0014 & 0,0005 & 0,0006 & 0,10 & 0,12 & 0,05 & $-20,08$ & $-18,22$ & $-26,16$ \\
\hline 10,00 & 0,0006 & 0,0008 & 0,0007 & 0,04 & 0,11 & 0,02 & $-27,27$ & $-19,47$ & $-32,80$ \\
\hline 12,50 & 0,0011 & 0,0007 & 0,0005 & 0,05 & 0,07 & 0,03 & $-26,43$ & $-23,65$ & $-31,21$ \\
\hline 16,00 & 0,0009 & 0,0009 & 0,0007 & 0,03 & 0,07 & 0,02 & $-30,13$ & $-23,19$ & $-34,17$ \\
\hline 20,00 & 0,0015 & 0,0018 & 0,0003 & 0,05 & 0,02 & 0,03 & $-26,18$ & $-33,93$ & $-29,52$ \\
\hline 25,00 & 0,0022 & 0,0016 & 0,0004 & 0,05 & 0,03 & 0,04 & $-26,08$ & $-31,92$ & $-28,85$ \\
\hline 31,50 & 0,0014 & 0,0021 & 0,0020 & 0,04 & 0,10 & 0,03 & $-28,73$ & $-20,03$ & $-30,79$ \\
\hline 40,00 & 0,0021 & 0,0026 & 0,0028 & 0,04 & 0,11 & 0,03 & $-28,70$ & $-18,96$ & $-29,93$ \\
\hline 50,00 & 0,0016 & 0,0017 & 0,0020 & 0,02 & 0,06 & 0,02 & $-34,75$ & $-23,78$ & $-35,29$ \\
\hline 63,00 & 0,0017 & 0,0011 & 0,0031 & 0,01 & 0,08 & 0,02 & $-36,77$ & $-21,98$ & $-36,46$ \\
\hline 80,00 & 0,0016 & 0,0013 & 0,0034 & 0,01 & 0,07 & 0,01 & $-38,86$ & $-23,25$ & $-37,97$ \\
\hline 100,00 & 0,0025 & 0,0016 & 0,0036 & 0,01 & 0,06 & 0,02 & $-36,58$ & $-24,64$ & $-35,42$ \\
\hline \multicolumn{4}{|c|}{ Maksimum } & 0,37 & 0,23 & 0,05 & $-8,66$ & $-12,76$ & $-25,49$ \\
\hline
\end{tabular}


were made, no significant change in the technical condition of the surface during this time period was found.

The results of the performed tests clearly show the dominance of vibrations in the transverse direction $y$, for the case of the $\mathrm{RC}$ cross-section, and vibrations in the vertical direction $z$, in the case of the AR crosssection. The recorded values of vibration accelerations in the vertical direction, for both types of surface were comparable. Vibration accelerations in the horizontal directions, in the case of the AR section reached up to about $60 \%$ of the values of similar accelerations recorded for the RC section.

$V L F$ load indicators calculated for people staying in the vicinity of the tram line did not reach concerning values, which indicates that there was no real impact on the comfort of neighboring buildings, assuming a distance of $10 \mathrm{~m}$ between them and the track. Analysis of $V L F$ levels calculated for buildings did not reveal any risk of vibration for the structure located at a distance of $10 \mathrm{~m}$ away. The Impact Damage Level calculated based on $V L F$ values did not indicate that the environment was exposed to harmful vibroacoustic effects caused by tram traffic.

The noise and vibration frequency range is related to the interactions and phenomena in the areas of railrail contact. The frequency characteristic of the vibration acceleration spectrum at the RC measurement point shows the dominance of the $40-200 \mathrm{~Hz}$ band for all vibration propagation directions. The frequency characteristic of the vibration acceleration spectrum at the AR measurement point is dominated by the $30-150$ $\mathrm{Hz}$ band, with differences for the analyzed directions. In the conducted tests, differences were found, whose detailed analysis will be the subject of further research.

\section{Bibliography / Bibliografia}

[1] Białasiewicz J.T.: Falki i aproksymacje. WNT, Warszawa 2004, ISBN 83-204-2971-4, s. 253.

[2] Cempel Cz.: Wibroakustyka stosowana, PWN, Warszawa 1989.

[3] Ciesielski R., Maciag E.: Drgania drogowe i ich wplyw na budynki. WKiE, Warszawa 1990, s. 248.

[4] Chudzikiewicz A., Korzeb J.: Simulation study of wheels wear in low-floor tram with independently rotating wheels, w: Archive of Applied Mechanics, vol. 419, $n r$ 88, 2018, ss. 175-192, DOI:10.1007/s00419-017-1301-6.

[5] Czechyra B., Kwaśnikowski J., Tomaszewski F.: Możliwości wykorzystania metod wibroakustycznych $w$ procesie oceny własności eksploatacyjnych tramwaju. Logistyka, 4/2011, Poznań, s. 172-180.

[6] Korzeb J.: Analiza drgań komunikacyjnych z zastosowaniem teorii falek. Prace Naukowe Politechniki Warszawskiej, seria Transport, z. 77, OWPW, Warszawa 2011r. str. 45-58.

[7] Korzeb J.: Dobór kryteriów oceny dynamicznych oddziatywań transportowych $w$ obszarach aglomeracji miejskich. Logistyka 6/2011, CD, s. 1717-1725.
Dla otrzymanych wyników wskaźników obciążenia drganiami $V L F$, każdorazowo wyznaczono zgodnie z zależnością (7) poziom szkodliwości oddziaływań (PSO). W żadnym $\mathrm{z}$ analizowanych przypadków nie przekroczył on wartości 0 , stąd nie ma podstaw do stwierdzenia, że w którymkolwiek z analizowanych przypadków występowało szkodliwe oddziaływanie drgań komunikacyjnych, w odległości 10 m od punktów pomiarowych.

\section{WNIOSKI}

W pracy przeanalizowano oddziaływanie odcinka torowiska tramwajowego, poddawanego ciagłej eksploatacji w okresie 5 lat. Odcinek pomiarowy podlegał obserwacji w okresie od modernizacji do czasu pomiarów, w którym nie stwierdzono znaczącej zmiany stanu technicznego nawierzchni.

Wyniki przeprowadzonych badań jednoznacznie wykazują dominację drgań w kierunku poprzecznym $y$, dla przypadku przekroju $\mathrm{RC}$, natomiast drgań w kierunku pionowym $z$, w przypadku przekroju AR. Zanotowane wartości przyspieszeń drgań w kierunku pionowym, dla obydwu rodzajów nawierzchni były porównywalne. Przyspieszenia drgań w kierunkach poziomych, w przypadku przekroju AR stanowiły około $60 \%$ wartości przyspieszeń w kierunkach poziomych, notowanych dla przekroju RC.

Wskaźniki obciążenia drganiami VLF obliczane dla ludzi przebywających w otoczeniu linii tramwajowej nie osiagały niepokojących wartości, co sugeruje brak wpływu na pogorszenie komfortu przebywania $\mathrm{w}$ sąsiadujących obiektach, przy założeniu odległości 10 m. Analiza wartości poziomów wskaźników VLF obliczanych dla budynków nie wykazała możliwości zagrożenia drganiami dla konstrukcji zlokalizowanych w odległości $10 \mathrm{~m}$. Oparty na wartościach $V L F$ obliczony Poziom Szkodliwości Oddziaływań - nie wykazał narażenia otoczenia na negatywne oddziaływania dynamiczne powodowane ruchem tramwajowym.

Zakres częstotliwościowy oddziaływań związany jest $\mathrm{z}$ relacją i zjawiskami kontaktowymi w obszarach styku otulina szyny-szyna. Charakter częstotliwościowy widma drgań w punkcie RC wykazuje dominowanie pasma 40-200 Hz dla wszystkich kierunków propagacji drgań. Charakter częstotliwościowy widma przyspieszeń drgań w punkcie AR wykazuje dominowanie pasma $30-150 \mathrm{~Hz}, \mathrm{z}$ występowaniem różnic dla analizowanych kierunków. W przeprowadzonych badaniach wykazano występowanie różnic, których szczegółowa analiza będzie przedmiotem kolejnych badań.

[8] Korzeb J.: Predykcja wybranych oddziatywań dynamicznych $w$ strefie wptywu infrastruktury transportowej, Prace Naukowe Politechniki Warszawskiej. Transport, nr 90, 2013, OW PW, ISBN 978-83-7814-111-2, 1-202 s. 
[9] Korzeb J., Chudzikiewicz A.: Evaluation of the vibration impacts in the transport infrastructure environment, Archive of Applied Mechanics, vol. Volume 85, nr 9, 2015, s. 1331-1342, DOI:10.1007/s00419-015-1029-0,

[10] Korzeb J., Ilczuk P.: Drgania i hałas w strefie oddziaływania linii tramwajowych. Logistyka 4/2014, CD/ str. 1997-2006.

[11] Nader M.: Drgania i hałas w transporcie. Wybrane zagadnienia. Oficyna Wydawnicza Politechniki Warszawskiej, ISBN 978-83-7814-543-1, 2016 r., $146 \mathrm{~s}$.

[12] Nader M., Korzeb J.: Dynamic interactions in the transport infrastructure environment. Vibrations in Physical Systems, vol. XXV. Ed. by Cempel Cz., Dobry M. Poznan University of Technology, ISBN 978-83-89333-43-8. Comprint, Poznań, 2012, pp. 459-468.

[13] Nader M., Korzeb J.: Analysis of the dynamic influence of urban transport on the environment. Proc. of 5th ICSCCE Athens, Patras University Press, ISBN:978-618-80115-0-2, Greece, 2012, pp. 67-74.

[14] Targosz J., Adamczyk J.: Badania i ocena wibroaktywności konstrukcji torowisk tramwajowych stosowanych $w$ Polsce. Logistyka, ISSN 1231-5478, nr 3/2012, s. 2267-2276.

[15] TransEko Sp.j.: Studium wykonalności dla projektu: „Obsługa pólnocnych obszarów Warszawy komunikacja tramwajowq $w$ zwiqzku z rozbudowq sieci metra oraz zakupem taboru”, na zlecenie Tramwajów Warszawskich, Warszawa, luty 2011.

[16] Zieliński T.P.: Cyfrowe przetwarzanie sygnałów. Od teorii do zastosowań. WKiE, ISBN 978-83-206-1640-8, Warszawa 2009, s. 832. 